\title{
Endothelin-receptor antagonists for aneurysmal subarachnoid hemorrhage: an updated meta- analysis of randomized controlled trials
}

\author{
Junpeng Ma, Siqing Huang, Lu Ma, Yi Liu, Hao Li and Chao You*
}

\begin{abstract}
Introduction: The previous meta-analysis on the use of endothelin-receptor antagonists (ETRAs) to treat aneurysmal subarachnoid hemorrhage $(\mathrm{SAH})$ has become outdated due to recently published phase 3 clinical trials. An up-to-date meta-analysis is needed to provide the best available evidence for the efficacy of ETRAs for aneurysmal SAH.

Methods: We performed a systematic review and meta-analysis of published randomized controlled trials that investigate efficacy of ETRAs in patients with aneurysmal SAH. Mortality, unfavorable outcome, delayed ischemic neurological deficit (DIND), delayed cerebral infarction (DCI), angiographic vasospasm and adverse events were analyzed. Meta-analysis was performed in terms of the risk ratio (RR) and 95\% confidence interval (CI).

Results: Five eligible studies were reviewed and analyzed, involving 2,595 patients. The pooled RRs of mortality and unfavorable outcome after SAH were $1.03(95 \% \mathrm{Cl}=0.77$ to 1.36$)$ and $1.07(95 \% \mathrm{Cl}=0.93$ to 1.22$)$, respectively. The pooled RRs were $0.87(95 \% \mathrm{Cl}=0.74$ to 1.03$)$ for $\mathrm{DCl}, 0.77(95 \% \mathrm{Cl}=0.66$ to 0.90$)$ for DIND, and $0.66(95 \% \mathrm{Cl}=0.57$ to 0.77$)$ for angiographic vasospasm. There were significant increases in lung complications $(\mathrm{RR}=1.80,95 \% \mathrm{Cl}=1.55$ to 2.09$)$, hypotension $(\mathrm{RR}=2.42,95 \% \mathrm{Cl}=1.78$ to 3.29$)$ and anemia $(\mathrm{RR}=1.47,95 \% \mathrm{Cl}=$ 1.19 to 1.83 ) in patients administered ETRAs.

Conclusion: There is no evidence that ETRAs could benefit clinical outcome in patients with SAH. Owing to the increased adverse events, further clinical trials of ETRAs in SAH patients should be more carefully formulated and designed. The present results also suggest that DCI may be a better outcome measure than vasospasm and DIND in SAH clinical trials and observational studies.
\end{abstract}

\section{Introduction}

Spontaneous subarachnoid hemorrhage $(\mathrm{SAH})$ is the extravasation of blood into the subarachnoid spaces filled with cerebrospinal fluid [1]. SAH accounts for 2 to $5 \%$ of all new strokes, with an overall incidence of about 9 per 100,000 person-years [2]. The outcome of patients after SAH is generally poor: about one-half of patients died after SAH and many survivors have long-term cognitive and neurological impairment [3-5]. Vasospasm is one of the most serious complications after $\mathrm{SAH}$, found in up to $70 \%$ of patients with SAH on angiography Vasospasm-associated clinical manifestation, delayed

\footnotetext{
* Correspondence: youchao028@163.com

Department of Neurosurgery, West China Hospital, Sichuan University, 37 Guoxuexiang Street, Chengdu 610041, P.R. China
}

ischemic neurological deficit (DIND) and delayed cerebral infarction (DCI) are the leading causes of mortality and morbidity after SAH and are widely considered potential therapeutic targets [6,7]. Clinical trials testing medical treatments for prevention of vasospasm have been disappointing, with only hemodynamic therapy and calcium antagonists having a beneficial effect, but the efficacy of these treatments is suboptimal [8-11].

Recently, there has been increasing interest in the use of endothelin-receptor antagonists (ETRAs) to prevent endothelin-mediated cerebral vasospasm after aneurysmal SAH. Endothelin is one of the most potent endogenous vasoconstrictors, which is responsible for the clinical manifestation of cerebral vasospasm following SAH [12]. Both experimental and clinical data demonstrate increased cerebrospinal fluid and plasma levels of 
endothelin expression in the presence of vasospasm. There is also an increase of endothelin-receptor expression in cerebral arteries following SAH $[13,14]$. Previous clinical trials and meta-analysis indicated that ETRAs can prevent both radiographic vasospasm and DINDs, but did not demonstrate that they can improve clinical outcomes [15]. Owing to recently published phase 3 clinical trials, the previous meta-analysis on the use of ETRAs to treat aneurysmal SAH has become outdated [16]. To provide the best available evidence for the effect and safety of ETRAs for aneurysmal SAH, we conducted an up-todate meta-analysis in the present article.

\section{Materials and methods}

The present study was performed according to the PRISMA guidelines (Additional File 1). The review protocol has not been registered previously.

\section{Type of studies included}

We included only published randomized controlled trials (RCTs) comparing ETRAs with no ETRAs or with placebo administration for patients with acute aneurysmal SAH.

\section{Types of outcome measures}

The following outcomes were evaluated: mortality at the end of scheduled follow-up; unfavorable outcome (either death or dependency) at the end of scheduled follow-up (dependency assessed at least 1 month after SAH); DCI and DIND; angiographic vasospasm; and adverse events.

We defined dependency as being dependent on others for activities of daily living; for example, having Glasgow Outcome Scale score <4, Extended Glasgow Outcome Scale $\leq 4$, modified Rankin Scale score graded 3 to 5, or Barthel Index 0 to $60[17,18]$. Angiographic vasospasm was defined as moderate (34 to $66 \%$ ) or severe (67 to $100 \%)$ arterial narrowing on digital subtraction angiography determined by neuroradiologists [19]. DIND was defined by a delayed decrease of consciousness by at least two Glasgow Coma Scale levels and/or an increase $\geq 2$ points on the abbreviated National Institutes of Health Stroke Scale and/or a new focal neurological deficit [16]. DCI was defined as confirmed new hypodensities on the computed tomography (CT) scan that were only attributable to cerebral vasospasm and delayed cerebral ischemia [20].

\section{Search strategy}

We performed a systematical search of the Cochrane Central Register of Controlled Trials, PubMed, MEDLINE, EMBASE and Science Citation Index Expanded (SCIEXPANDED) from 1980 to July 2012. The details of full electronic search strategies are presented in Additional File 2. The reference lists of all relevant papers and literature reviews were checked. In addition, we contacted researchers and study authors for further information where possible.

\section{Study selection and data extraction}

Three review authors (JM, HL and SH) independently screened the titles, abstracts and keywords of citations obtained from the searches of the electronic databases and excluded studies that were clearly irrelevant. We obtained the full text of the remaining studies and the same three review authors independently assessed which trials met the predefined inclusion criteria. Disagreements were resolved by consensus between investigators. The following data of included studies were extracted independently by the same three authors: first author, year of publication, journal, study center, study population characteristics (inclusion and exclusion criteria, age, gender, similarity of groups at baseline, severity of SAH), sample size, interventions for ETRAs (time of initiated administration, type, dose, duration, route of administration), and treatment of aneurysm (clip or coil). The methodological quality of each trial was evaluated using the Jadad scale [21] and the risk of bias assessment tool in the Cochrane Handbook for Systematic Reviews of Interventions [22]. The criteria included randomization, allocation concealment, blinding, and an explanation of withdrawal or loss to follow-up. Clinical trials with Jadad scores $\geq 3$ were considered to have lower bias risks. Any discrepancies were resolved by consensus between investigators.

\section{Statistical analysis and assessment for bias}

Meta-analysis was performed to calculate the risk ratio (RR) and 95\% confidence interval (CI) via a fixed-effect model if there is no evidence of statistical heterogeneity. The random-effects model was employed to pool studies when statistical heterogeneity occurred. We intended to performed subgroup analysis according to the type and dose of ETRAs, as well as the grade of SAH patients (high-grade patients vs. low-grade patients) and the treatment of intracranial aneurysm (clipped patients vs. coiled patients) if possible. We assessed and quantified statistical heterogeneity for each pooled summary estimate using Cochran's $Q$ statistic and the $I^{2}$ statistic, respectively. Substantial heterogeneity will be considered to exist with $I^{2}>50 \%$ and chi-squared test $P<0.1$. All analyses were performed using the Review Manager Software, RevMan 5.1 (Version 5.1. Copenhagen: The Nordic Cochrane Centre, The Cochrane Collaboration, 2011).

\section{Results}

\section{Trial selection and characteristics}

The combined search strategy identified 1,673 citations (Figure 1). After title, abstract and full-text screening, five completed RCTs satisfied all inclusion criteria for final 


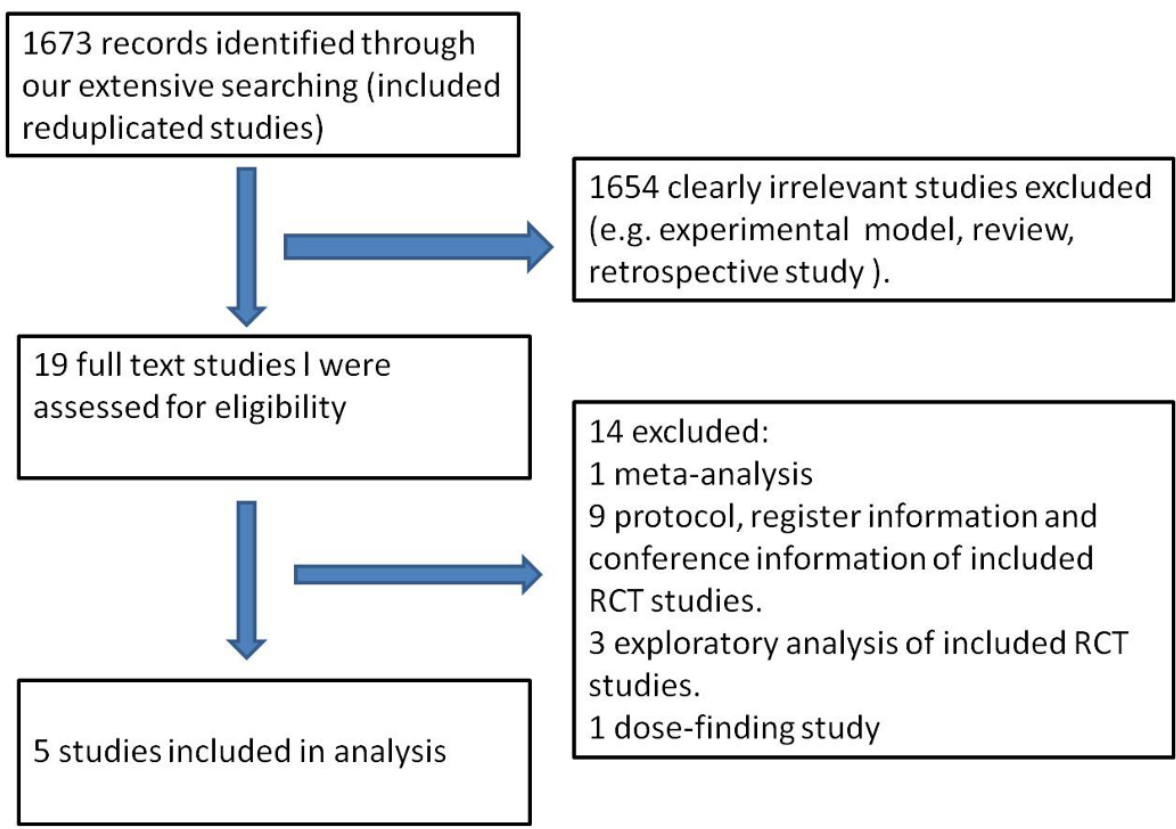

Figure 1 Flow diagram for study selection. RCT, randomized controlled trial.

analysis and included a total of 2,595 patients [16,23-26]. Four trials, involving 2,175 patients, used the endothelinA antagonist clazosentan compared with placebo. The other RCT enrolled 420 patients to receive either placebo or a mixed endothelin-A/B antagonist (TAK-044). Details of the included studies are presented in Table 1.

\section{Assessment of trial quality}

Five eligible studies were assessed for risks of bias using both the Cochrane Handbook for Systematic Reviews of Interventions and the Jadad scale. All these trials were found to have lower bias risks (Jadad score $>3$ ). Details of our assessment of the risk of bias in the included studies are presented in Table 2. We intended to access publication bias using a funnel plot and linear regression test, but there were too few included studies to enable meaningful analysis.

\section{Effects of interventions \\ Mortality and unfavorable outcome}

Five studies with 2,595 patients were available for analysis of mortality and four studies with 2,547 patients were available for analysis of unfavorable outcome (either death or dependency). The pooled RR for mortality at the end of scheduled follow-up was 1.03 (95\% CI $=0.77$ to 1.36). Heterogeneity: $\chi^{2}=0.95$, degrees of freedom $(\mathrm{df})=4(P=0.92) ; I^{2}=0 \%$ (Figure 2$)$. The pooled RR for unfavorable outcome at the end of scheduled followup was 1.07 ( $95 \% \mathrm{CI}=0.93$ to 1.22 ). Heterogeneity: $\chi^{2}=3.10, \mathrm{df}=3(P=0.38) ; I^{2}=3 \%$ (Figure 3$)$.

\section{Angiographic vasospasm}

Three studies presented the data for angiographic vasospasm, involving 1,588 patients. The pooled RR for angiographic vasospasm was $0.66(95 \% \mathrm{CI}=0.57$ to 0.77$)$. Heterogeneity: $\chi^{2}=2.66, \mathrm{df}=2(P=0.26) ; I^{2}=25 \%$ (Figure 4). One should note that not all patients in the CONSCIOUS-3 study underwent angiograms (several patients underwent computed tomography angiography instead of digital subtraction angiography) [26], so the data from the CONSCIOUS-3 study were not useful to calculate the rate of vasospasm in this meta-analysis.

\section{Delayed cerebral infarction and delayed ischemic} neurological deficit

All five studies recorded DCI, involving 2,576 patients. The pooled RR for DCI was $0.87(95 \% \mathrm{CI}=0.74$ to 1.03$)$. Heterogeneity: $\chi^{2}=7.25, \mathrm{df}=4(P=0.12) ; I^{2}=45 \%$ (Figure 5). Four studies of 2,547 patients reported DIND. The pooled RR for DIND was 0.77 (95\% CI $=0.66$ to 0.90). Heterogeneity: $\chi^{2}=1.32, \mathrm{df}=3(P=0.72) ; I^{2}=0 \%$ (Figure 6).

\section{Adverse events}

All five studies reported adverse events. The targeted adverse events under observation mainly contained lung complications, anemia, hypotension, hepatobiliary events, cerebral hemorrhage and cardiac ischemic events. The pooled RR for each adverse event is presented in Figure 7. There were significant increases in lung complications $(\mathrm{RR}=1.80,95 \% \mathrm{CI}=1.55$ to 2.09$)$, hypotension $(\mathrm{RR}=2.42,95 \% \mathrm{CI}=1.78$ to 3.29$)$ and anemia $(\mathrm{RR}=1.47,95 \% \mathrm{CI}=1.19$ to 1.83$)$. 
Table 1 Characteristics of the randomized controlled trials involving use of ETRAs in patients with SAH

\begin{tabular}{|c|c|c|c|c|c|c|c|c|c|}
\hline $\begin{array}{l}\text { Included } \\
\text { study/year }\end{array}$ & Center/area & $\begin{array}{l}\text { Participants } \\
\text { (age/grade) }\end{array}$ & $\begin{array}{l}\text { Number of } \\
\text { participants } \\
\text { (ETRA/ } \\
\text { placebo) }\end{array}$ & $\begin{array}{l}\text { Treatment } \\
\text { of } \\
\text { aneurysm }\end{array}$ & $\begin{array}{l}\text { ETRA (time of } \\
\text { initiation, } \\
\text { routine) }\end{array}$ & Dose $(n)$ & $\begin{array}{l}\text { Duration } \\
\text { of } \\
\text { treatment }\end{array}$ & Primary outcome & Secondary outcomes \\
\hline $\begin{array}{l}\text { Shaw and } \\
\text { colleagues, } \\
2000 \text { [23] }\end{array}$ & $\begin{array}{l}\text { Multicenter/ } \\
\text { Europe }\end{array}$ & $\begin{array}{l}>18 \text { years old, } \\
\text { WFNS } 1 \text { to } 4 \\
\text { (79\% grade } 1 \text { to } \\
\text { 2) }\end{array}$ & $420(207 / 213)$ & $\begin{array}{l}75 \% \\
\text { clipped, } 9 \% \\
\text { coiled }\end{array}$ & $\begin{array}{l}\text { TAK-044 } \\
\text { (within } 96 \\
\text { hours, } \\
\text { intravenously) }\end{array}$ & $\begin{array}{l}\leq 50 \mathrm{mg} \text { three } \\
\text { times per day }\end{array}$ & 10 days & DND within 3 months & $\begin{array}{l}\text { DND within } 10 \text { days; } \mathrm{DCl} \text { within } 3 \text { months; } \\
\text { GOS at } 3 \text { months; adverse events }\end{array}$ \\
\hline $\begin{array}{l}\text { Vajkoczy } \\
\text { and } \\
\text { colleagues, } \\
2005[24]\end{array}$ & $\begin{array}{l}\text { Multicenter/ } \\
\text { Germany }\end{array}$ & $\begin{array}{l}18 \text { to } 65 \text { years } \\
\text { old, } \mathrm{HH} 3 \text { to } 4\end{array}$ & $29(13 / 16)$ & $\begin{array}{l}100 \% \\
\text { clipped }\end{array}$ & $\begin{array}{l}\text { Clazosentan } \\
\text { (within } 48 \\
\text { hours, } \\
\text { intravenously) }\end{array}$ & $0.2 \mathrm{mg} / \mathrm{kg} / \mathrm{hour}$ & 14 days & $\begin{array}{l}\text { Incidence and severity } \\
\text { of angiographic } \\
\text { vasospasm on day } 8 \\
\text { post SAH }\end{array}$ & $\mathrm{DCl}$ at 14 days; adverse events \\
\hline $\begin{array}{l}\text { CONSCIOUS- } \\
1,2008[25]\end{array}$ & $\begin{array}{l}\text { Multicenter/ } \\
\text { North } \\
\text { America and } \\
\text { Europe }\end{array}$ & $\begin{array}{l}18 \text { to } 70 \text { years } \\
\text { old, WFNS } 1 \text { to } 4 \\
\text { (74\% grade } 1 \text { to } \\
\text { 2) }\end{array}$ & $409(313 / 96)$ & $\begin{array}{l}45 \% \\
\text { clipped }\end{array}$ & $\begin{array}{l}\text { Clazosentan } \\
\text { (within } 56 \\
\text { hours, } \\
\text { intravenously) }\end{array}$ & $\begin{array}{l}1 \mathrm{mg} / \text { hour (108), } \\
5 \mathrm{mg} / \text { hour (111), } \\
15 \mathrm{mg} / \text { hour (98) }\end{array}$ & 14 days & $\begin{array}{l}\text { Moderate or severe } \\
\text { vasospasm within } 14 \\
\text { days }\end{array}$ & $\begin{array}{l}\text { Morbidity and mortality at } 6 \text { and } 12 \\
\text { weeks; DIND at } 14 \text { days; DCI at } 6 \text { weeks; } \\
\text { rescue therapy within } 14 \text { days; adverse } \\
\text { events }\end{array}$ \\
\hline $\begin{array}{l}\text { CONSCIOUS- } \\
2,2011[16]\end{array}$ & $\begin{array}{l}\text { Multicenter/ } \\
\text { North } \\
\text { America and } \\
\text { Europe }\end{array}$ & $\begin{array}{l}18 \text { to } 75 \text { years } \\
\text { old, WFNS } 1 \text { to } 4 \\
\text { (78\% grade } 1 \text { to } \\
\text { 2) }\end{array}$ & $\begin{array}{l}1,147(764 / \\
383)\end{array}$ & $\begin{array}{l}100 \% \\
\text { clipped }\end{array}$ & $\begin{array}{l}\text { Clazosentan } \\
\text { (within } 56 \\
\text { hours, } \\
\text { intravenously) }\end{array}$ & $5 \mathrm{mg} / \mathrm{hour}$ & 14 days & $\begin{array}{l}\text { Mortality and } \\
\text { vasospasm-related } \\
\text { morbidity within } 6 \\
\text { weeks post SAH }\end{array}$ & $\begin{array}{l}\text { Dichotomized GOSE score at } 12 \text { weeks; } \\
\text { DCl, DIND, rescue therapy at } 6 \text { weeks; } \\
\text { adverse events }\end{array}$ \\
\hline $\begin{array}{l}\text { CONSCIOUS- } \\
3,2012[26]\end{array}$ & $\begin{array}{l}\text { Multicenter/ } \\
\text { North } \\
\text { America and } \\
\text { Europe }\end{array}$ & $\begin{array}{l}18 \text { to } 75 \text { years } \\
\text { old, WFNS } 1 \text { to } 4 \\
\text { (80\% grade } 1 \text { to } \\
\text { 2) }\end{array}$ & $571(382 / 189)$ & $\begin{array}{l}100 \% \\
\text { coiling }\end{array}$ & $\begin{array}{l}\text { Clazosentan } \\
\text { (within } 56 \\
\text { hours, } \\
\text { intravenously) }\end{array}$ & $\begin{array}{l}5 \mathrm{mg} / \text { hour (194), } \\
15 \mathrm{mg} / \text { hour (188) }\end{array}$ & 14 days & $\begin{array}{l}\text { Mortality and } \\
\text { vasospasm-related } \\
\text { morbidity within } 6 \\
\text { weeks post SAH }\end{array}$ & $\begin{array}{l}\text { Dichotomized GOSE score at } 12 \text { weeks; } \\
\text { DCI, DIND, rescue therapy at } 6 \text { weeks; } \\
\text { death at } 12 \text { weeks; adverse events }\end{array}$ \\
\hline
\end{tabular}

DCl, delayed intracerebral infarction; DIND, delayed ischemic neurological deficit; DND, delayed neurological deterioration; ETRA, endothelin-receptor antagonist; GOS, Glasgow Outcome Scale; GOSE, Extended

Glasgow Outcome Scale; HH, Hunt-Hess grade; SAH, subarachnoid hemorrhage; WFNS, World Federation of Neurological Surgeons grade. 
Table 2 Quality indicators and assessment of risk of bias in the included randomized controlled trials

\begin{tabular}{|c|c|c|c|c|c|}
\hline Quality indicators/studies & $\begin{array}{l}\text { Shaw and colleagues } \\
\text { [23] }\end{array}$ & $\begin{array}{l}\text { Vajkoczy and colleagues } \\
\text { [24] }\end{array}$ & $\begin{array}{l}\text { CONSCIOUS-1 } \\
{[25]}\end{array}$ & $\begin{array}{l}\text { CONSCIOUS-2 } \\
{[16]}\end{array}$ & $\begin{array}{l}\text { CONSCIOUS-3 } \\
{[26]}\end{array}$ \\
\hline Randomized controlled study & Yes & Yes & Yes & Yes & Yes \\
\hline $\begin{array}{l}\text { Appropriate random sequence } \\
\text { generation }\end{array}$ & Yes & Unclear & Unclear & Yes & Yes \\
\hline Allocation concealment & Unclear & Unclear & Unclear & Yes & Yes \\
\hline $\begin{array}{l}\text { Blinding of participants and } \\
\text { personnel }\end{array}$ & Yes & Yes & Yes & Yes & Yes \\
\hline Blinding of outcome assessment & Unclear & Yes & Yes & Yes & Yes \\
\hline $\begin{array}{l}\text { Explanation for withdrawals and } \\
\text { dropouts }\end{array}$ & No & Yes & Yes & Yes & Yes \\
\hline Jadad scale & 4 & 4 & 4 & 5 & 5 \\
\hline
\end{tabular}

\section{Subgroup analysis}

As the data for subgroup analysis between the coiling group and the clipping group were inadequate and unavailable, we only performed subgroup analysis according to the type (clazosentan vs. TAK-044; Figures 2, 3, 5, 6) and dose (clazosentan, $5 \mathrm{mg} /$ hour vs. $15 \mathrm{mg} /$ hour; Figure 8 ) of ETRA. The estimate for mortality in the clazosentan group $(\mathrm{RR}=1.04,95 \% \mathrm{CI}=0.72$ to $1.51, n=2,175)$ was not statistically different from that for the TAK-044 group $(\mathrm{RR}=1.00,95 \% \mathrm{CI}=0.64$ to $1.56, n=420)$ with $P=0.88$. There was no difference in treatment effect on unfavorable outcome, DCI and DIND in subgroup analysis according to the type of ETRA. There was also no statistical difference for mortality and unfavorable outcome when analyzed according to the dose of ETRA.

\section{Discussion}

In accordance with the previous meta-analysis, the results of our updated meta-analysis did not find evidence that ETRAs could provide beneficial clinical outcome in patients with SAH. Although ETRAs can significantly reduce angiographic vasospasm (P $<0.00001)$ and DIND $(P=0.001)$, they did not improve overall mortality and unfavorable outcome. There was

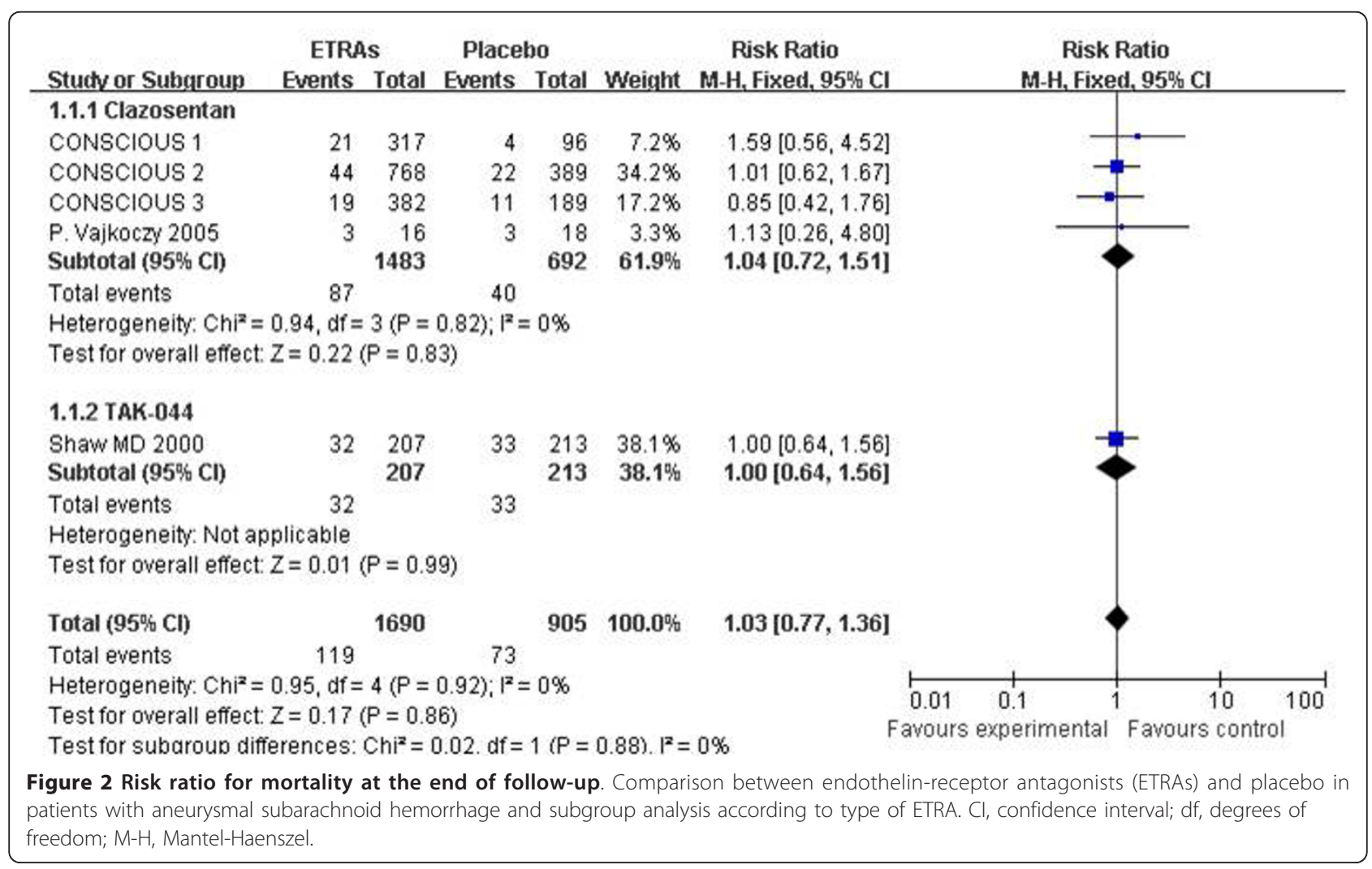




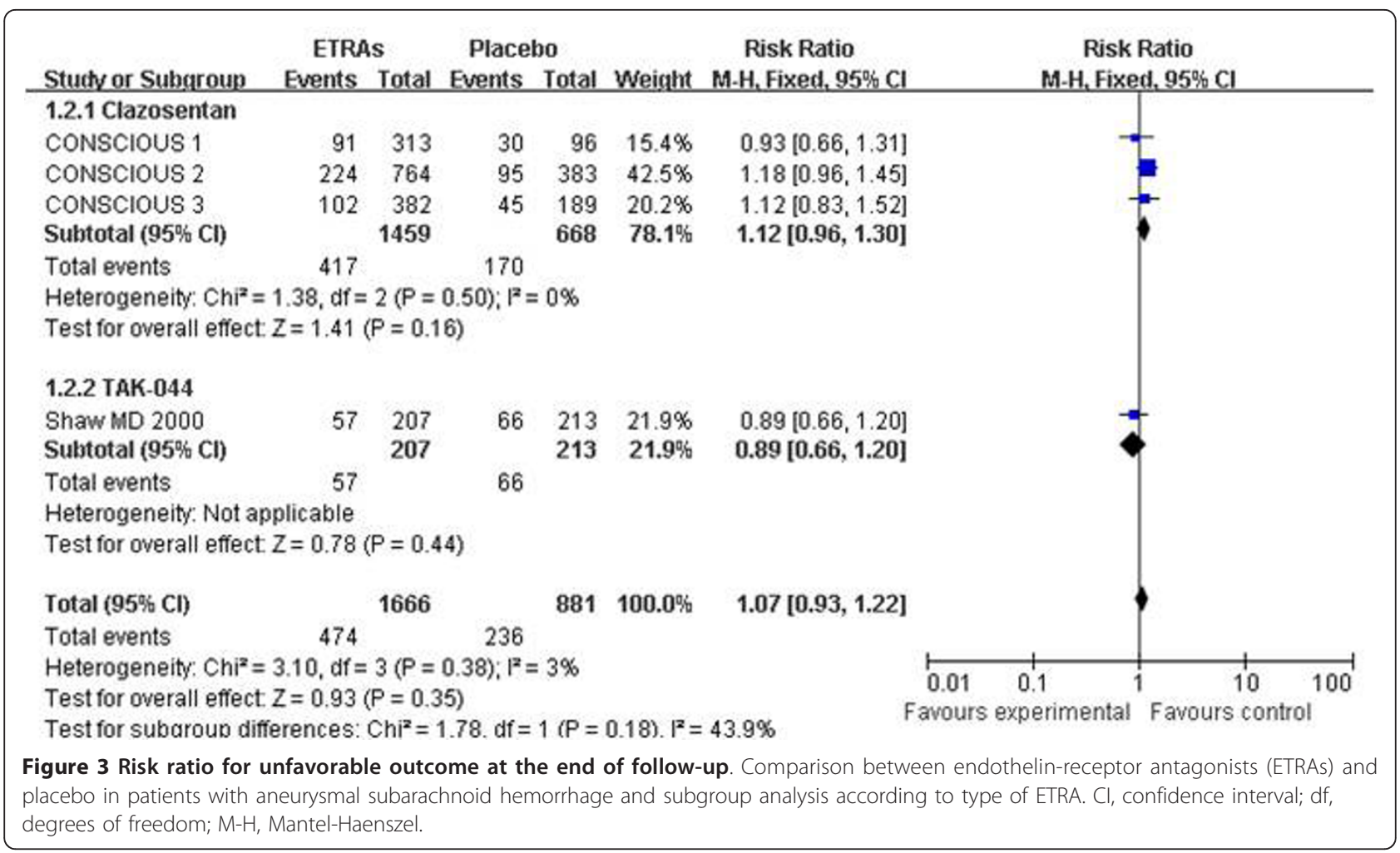

also no significant reduction in DCI. In addition, pulmonary complications, anemia and hypotension were more common in patients receiving ETRAs compared with placebo. The disappointing results do not support the routine use of ETRAs in SAH patients. As hypotension and pulmonary complications are independently associated with poor outcome after SAH [27], further clinical trials of ETRAs in SAH patients should be more carefully formulated and designed.

The present data revealed that there was obvious dissociation between angiographic vasospasm and clinical outcome measurements. This dissociation could result from increased adverse events, methodological problems, insensitivity of clinical outcome, sample size and other possible processes other than angiographic vasospasm contributing to poor outcome $[28,29]$. Since signs of cerebral ischemia and vasospasm are sometimes reversible, data on vasospasm or DIND in SAH clinical trials may not have been important. In concordance with a recent consensus paper, this meta-analysis also supports the suggestion that DCI on CT scan is a better outcome measure in observational studies and clinical trials than vasospasm and DIND [30]. However, because identifying DCI from all causes of CT hypointensities may be difficult with only a plain CT scan,

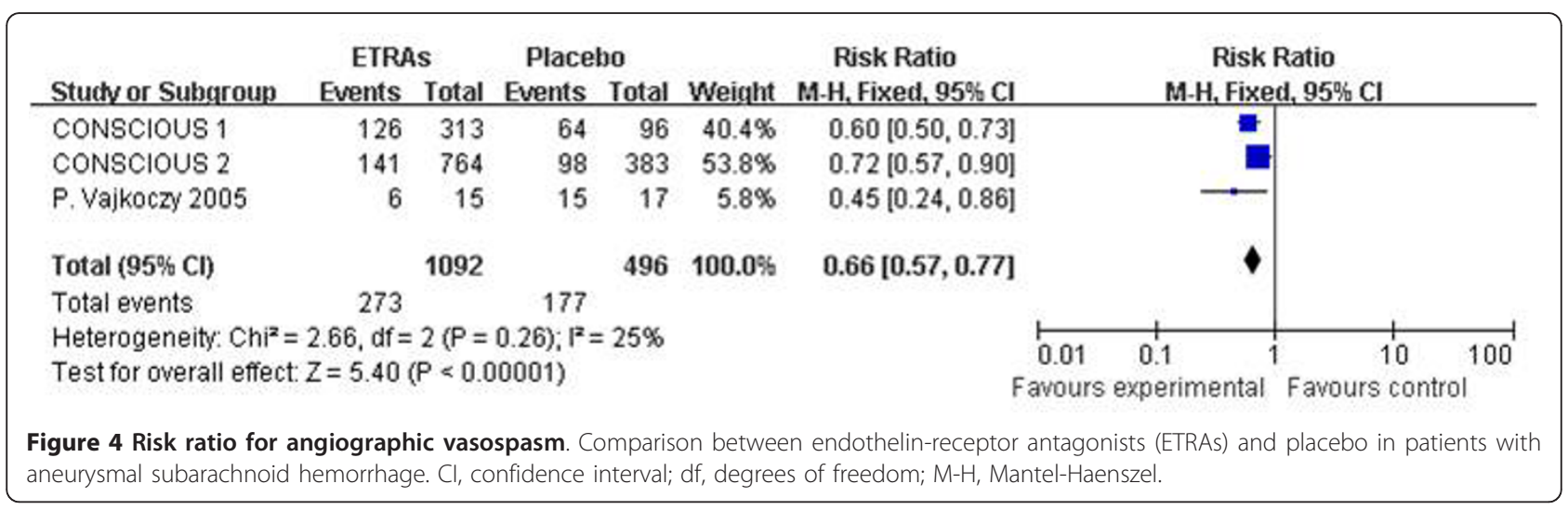




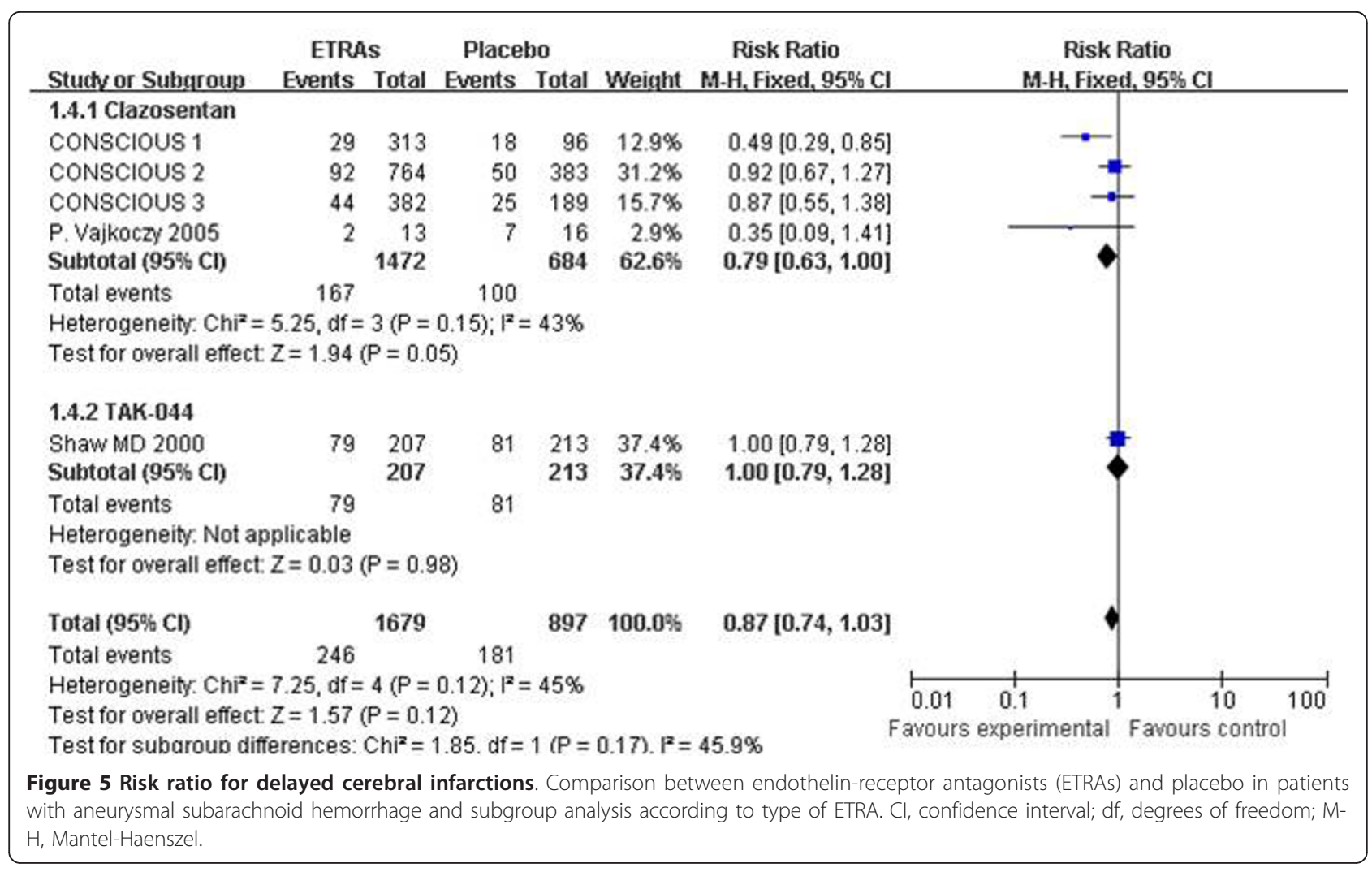

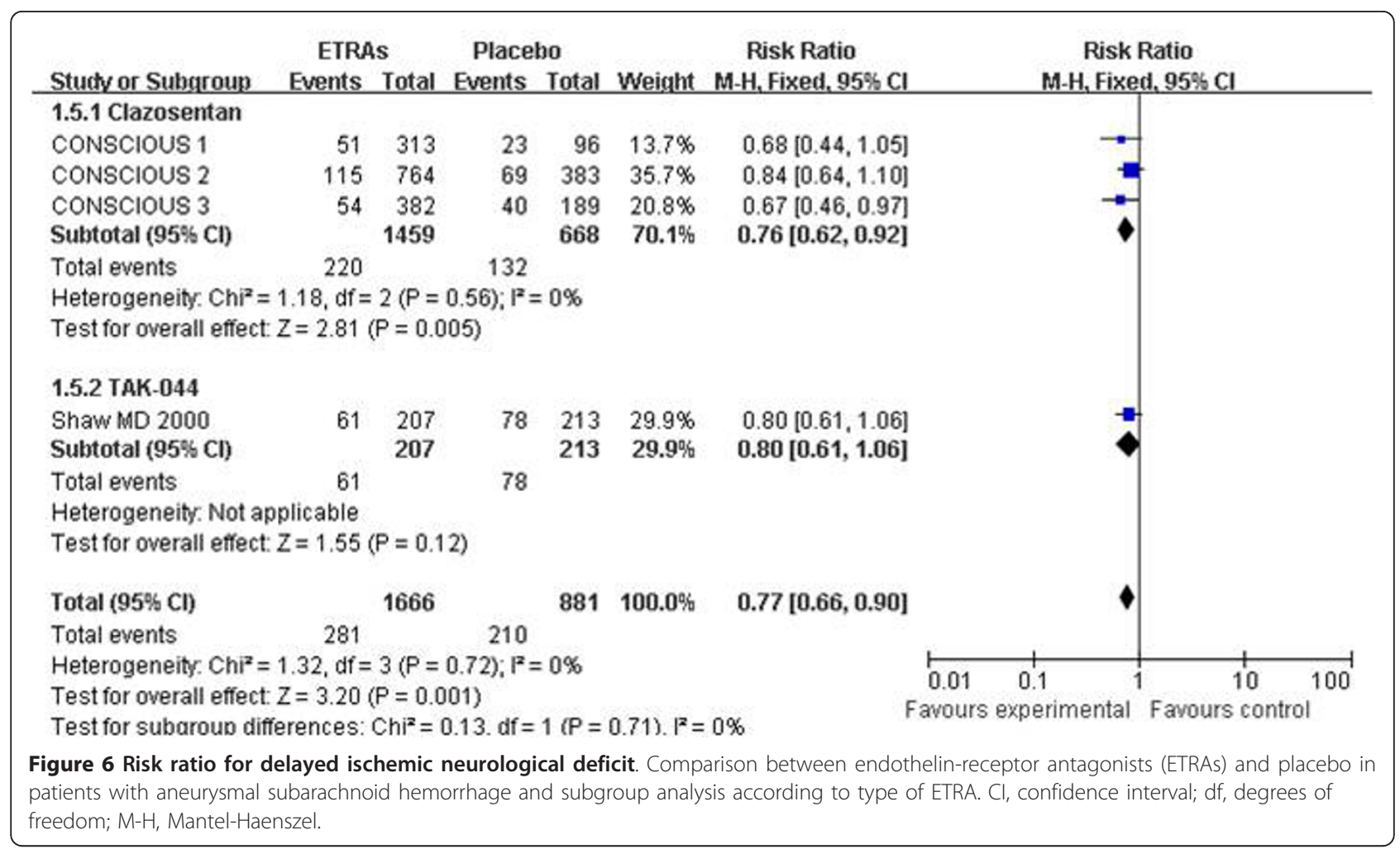


future advanced techniques and surrogate outcomes should also be designed and introduced [31].

In any meta-analysis, the possibility of publication bias should be considered a potential threat to validity. In this paper, however, we believe that the risk of publication bias affecting the results is minimal due to our extensive and sensitive searching. The high quality of the included RCTs also reduced potential sources of risk of bias. 


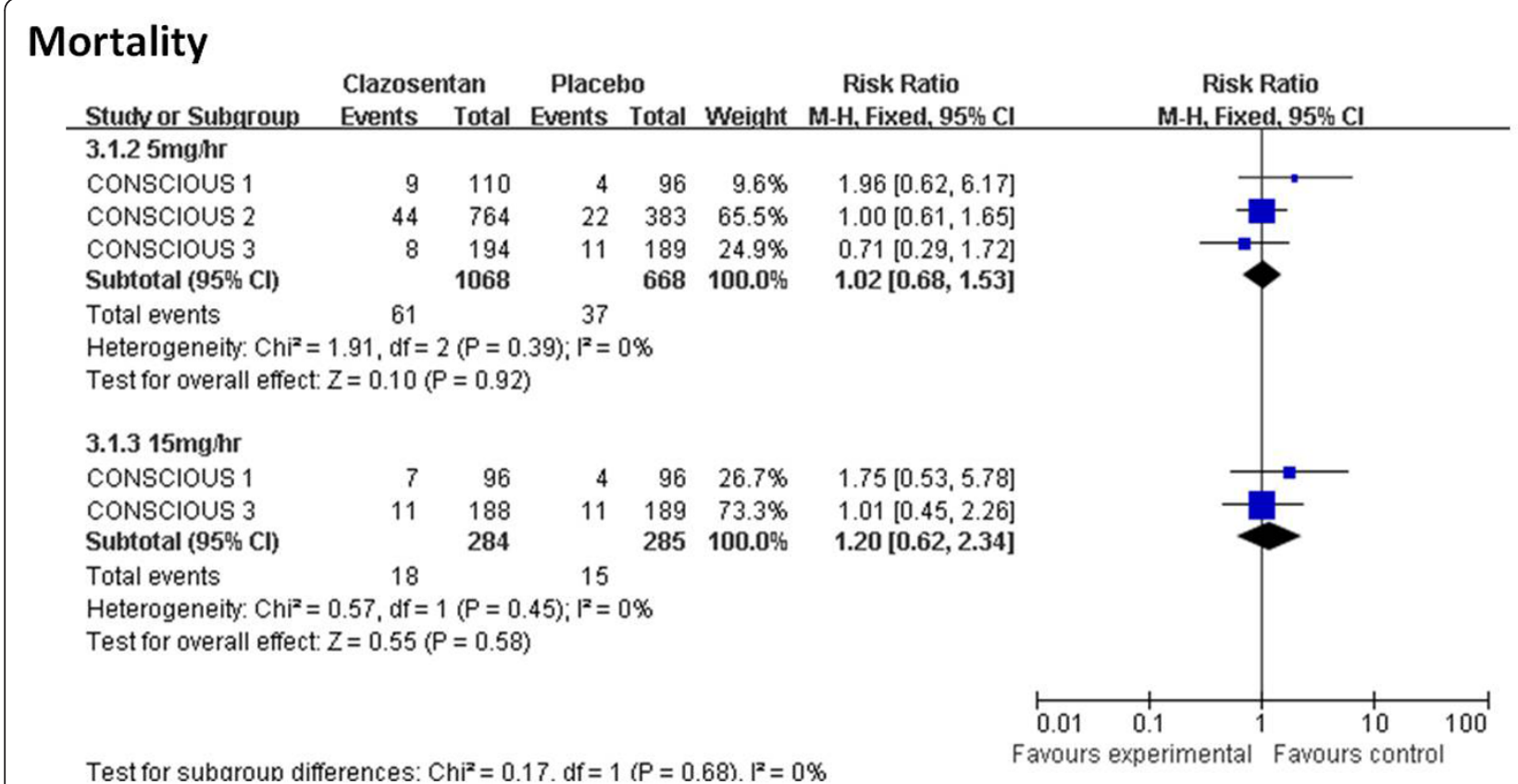

\section{Unfavorable Outcome}

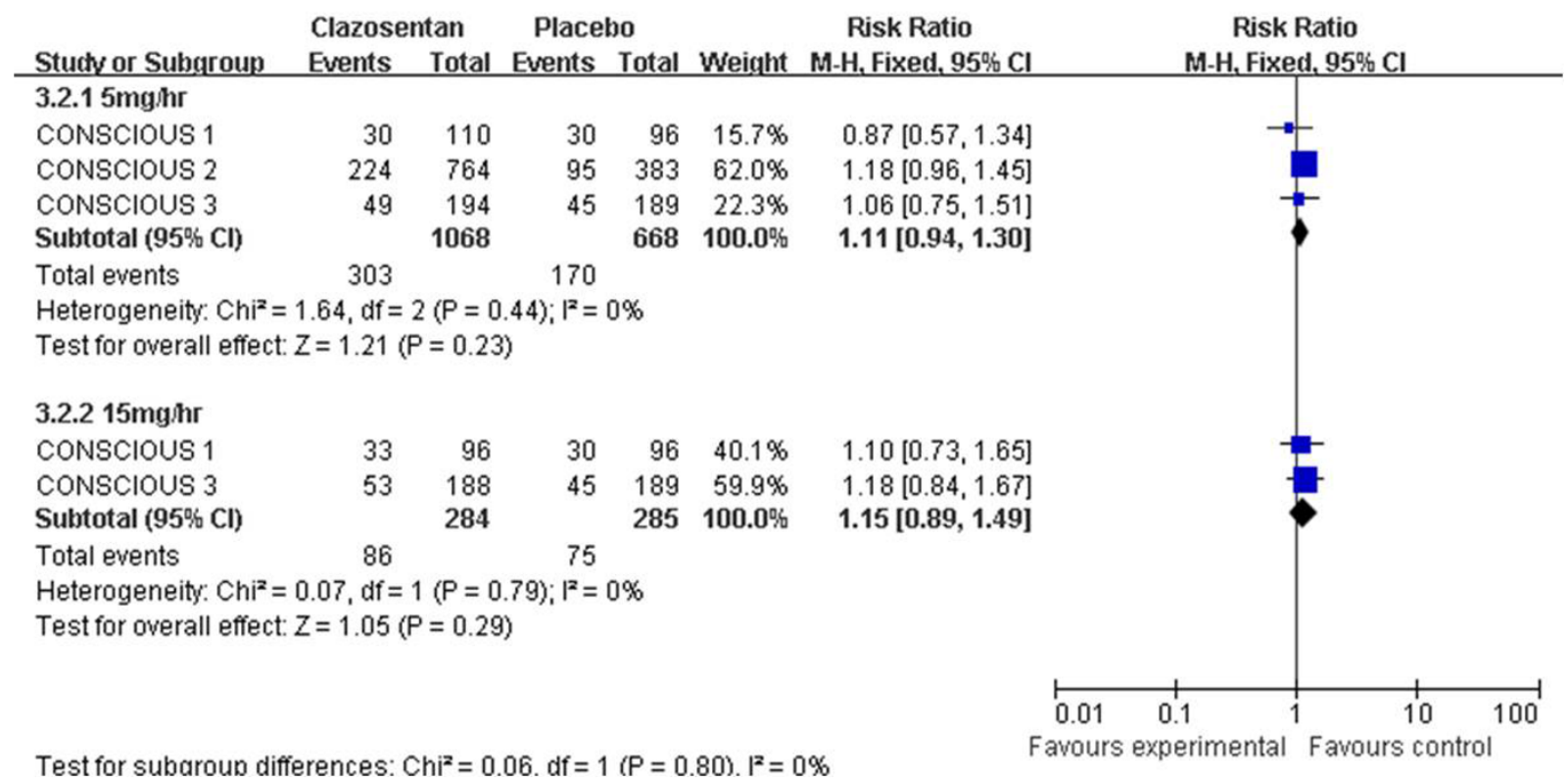

Figure 8 Mortality and unfavorable outcome according to clazosentan dose. Subgroup analysis for mortality and unfavorable outcome at the end of follow-up according to the dose of clazosentan. Cl, confidence interval; df, degrees of freedom M-H, Mantel-Haenszel.

There is no evidence for statistical heterogeneities in pooled analysis of each outcome. However, in this metaanalysis, four limitations should be noted. First, angiography was not routinely performed in all included studies this would decrease the correlations among vasospasm, DCI, and clinical outcome. Second, explicit definitions for hypotension or pulmonary complications were not classified in the included studies. Similarly, the definition of DIND is not identical between the CONSCIOUS studies and the TAK-044 trial. Third, four included RCTs and our paper use angiographic vasospasm as an outcome measure, but vasospasm of microvessels cannot be visualized on angiography and there is no established criterion for the definition of angiographic vasospasm. 
Fourth, the treatment of intracranial aneurysm in each included study is not unanimously identical (Table 1). We intended to obtain unpublished data for subgroup analysis (coiling vs. clipping), but no additional data are available to construct the subgroup analysis. The confounding factor of different treatments for intracranial aneurysm should be considered a source for risk of bias and heterogeneities for the pooled data.

\section{Conclusion}

There is no evidence that ETRAs could benefit clinical outcome in patients with SAH. Owing to the increased adverse events, further clinical trials of ETRAs in SAH patients should be more carefully formulated and designed. The present results also suggest that DCI may be a better outcome measure than vasospasm and DIND in clinical trials and observational studies.

\section{Key messages}

- Pilot studies suggested that ETRAs prevent both radiographic vasospasm and DINDs after SAH, but did not indicate that they could improve clinical outcome. Owing to recently published phase 3 clinical trials, the previous meta-analysis on the use of ETRAs to treat aneurysmal SAH has become outdated.

- An up-to-date systemic review and meta-analysis indicates that ETRAs associated with increased adverse events and did not benefit clinical outcome in patients with SAH. Further clinical trials of ETRAs in SAH patients should be more carefully formulated and designed.

\section{Additional material}

Additional file 1: a table presenting the PRISMA guidelines.

Additional file 2: a diagram presenting the search strategy.

\begin{abstract}
Abbreviations
Cl: confidence interval; CT: computed tomography; DCl: delayed cerebral infarction; df: degrees of freedom; DIND: delayed ischemic neurological deficit; ETRA: endothelin-receptor antagonist; RCT: randomized controlled trial; RR: risk ratio; SAH: subarachnoid hemorrhage.
\end{abstract}

\section{Authors' contributions}

All authors contributed to the design of the study. JM, HL and $\mathrm{SH}$ undertook the searches and screened the citations for eligibility. JM, HL and $\mathrm{SH}$ assessed the quality of papers, extracted data, and entered data into RevMan. JM, LM and YL drafted the manuscript. CY moderated disagreements during data collection, analyzed and interpreted data, and helped to draft the manuscript. All authors revised the manuscript and approved the final version.

\section{Competing interests}

The authors declare that they have no competing interests.

Received: 20 May 2012 Revised: 20 September 2012

Accepted: 9 October 2012 Published: 18 October 2012
References

1. Suarez Jl, Tarr RW, Selman WR: Aneurysmal subarachnoid hemorrhage. N Engl J Med 2006, 354:387-396.

2. de Rooij NK, Linn FH, van der Plas JA, Algra A, Rinkel GJ: Incidence of subarachnoid haemorrhage: a systematic review with emphasis on region, age, gender and time trends. J Neurol Neurosurg Psychiatry 2007, 78:1365-1372.

3. Hackett ML, Anderson CS: Health outcomes 1 year after subarachnoid hemorrhage. An international population-based study. Neurology 2000, 55:658-662.

4. Mayer SA, Kreiter KT, Copeland D, Bernardini GL, Bates JE, Peery S, Claassen J, Du YE, Connolly ES Jr: Global and domain-specific cognitive impairment and outcome after subarachnoid hemorrhage. Neurology 2002, 59:1750-1758.

5. Nieuwkamp DJ, Setz LE, Algra A, Linn FH, de Rooij NK, Rinkel GJ: Changes in case fatality of aneurysmal subarachnoid haemorrhage over time, according to age, sex, and region: a meta-analysis. Lancet Neurol 2009, 8:635-642

6. Crowley RW, Medel R, Kassell NF, Dumont AS: New insights into the causes and therapy of cerebral vasospasm following subarachnoid hemorrhage. Drug Discov Today 2008, 13:254-260.

7. Fergusen S, Macdonald RL: Predictors of cerebral infarction in patients with aneurysmal subarachnoid hemorrhage. Neurosurgery 2007, 60:658-667.

8. Wong GK, Boet R, Poon WS, Chan MT, Gin T, Ng SC, Zee BC: Intravenous magnesium sulphate for aneurysmal subarachnoid hemorrhage: an updated systemic review and meta-analysis. Crit Care 2011, 15:R52.

9. Dorhout Mees SM, Rinkel GJ, Feigin VL, Algra A, van den Bergh WM, Vermeulen $M$, van Gijn J: Calcium antagonists for aneurysmal subarachnoid haemorrhage. Cochrane Database Syst Rev 2007, 18: CD000277.

10. Rinkel GJ, Feigin VL, Algra A, van Gijn J: Circulatory volume expansion therapy for aneurysmal subarachnoid haemorrhage. Cochrane Database Syst Rev 2004, 18:CD000483.

11. Zhang S, Wang L, Liu M, Wu B: Tirilazad for aneurysmal subarachnoid haemorrhage. Cochrane Database Syst Rev 2010, 17:CD006778.

12. Suhardja A: Mechanisms of disease: roles of nitric oxide and endothelin1 in delayed cerebral vasospasm produced by aneurysmal subarachnoid hemorrhage. Nat Clin Pract Cardiovasc Med 2004, 1:110-116.

13. Mascia L, Fedorko L, Stewart DJ, Mohamed F, terBrugge K, Ranieri VM, Wallace MC: Temporal relationship between endothelin-1 concentrations and cerebral vasospasm in patients with aneurysmal subarachnoid hemorrhage. Stroke 2001, 32:1185-1190.

14. Suzuki K, Meguro K, Sakurai T, Saitoh Y, Takeuchi S, Nose T: Endothelin-1 concentration increases in the cerebrospinal fluid in cerebral vasospasm caused by subarachnoid hemorrhage. Surg Neurol 2000, 53:131-135.

15. Kramer A, Fletcher J: Do endothelin-receptor antagonists prevent delayed neurological deficits and poor outcomes after aneurysmal subarachnoid hemorrhage?: a meta-analysis. Stroke 2009, 40:3403-3406.

16. Macdonald RL, Higashida RT, Keller E, Mayer SA, Molyneux A, Raabe A, Vajkoczy P, Wanke I, Bach D, Frey A, Marr A, Roux S, Kassell N: Clazosentan, an endothelin receptor antagonist, in patients with aneurysmal subarachnoid haemorrhage undergoing surgical clipping: a randomised, double-blind, placebo-controlled phase 3 trial (CONSCIOUS-2). Lancet Neurol 2011, 10:618-625.

17. Jennett $B$, Bond $M$ : Assessment of outcome after severe brain damage. Lancet 1975, 1:480-484.

18. Sulter G, Steen C, De Keyser J: Use of the Barthel index and modified Rankin scale in acute stroke trials. Stroke 1999, 30:1538-1541.

19. Vergouwen MD, llodigwe D, Macdonald RL: Cerebral infarction after subarachnoid hemorrhage contributes to poor outcome by vasospasmdependent and -independent effects. Stroke 2011, 42:924-929.

20. Jaeger M, Schuhmann MU, Soehle $M$, Nagel C, Meixensberger J: Continuous monitoring of cerebrovascular autoregulation after subarachnoid hemorrhage by brain tissue oxygen pressure reactivity and its relation to delayed cerebral infarction. Stroke 2007, 38:981-986.

21. Jadad AR, Moore RA, Carroll D, Jenkinson C, Reynolds DJ, Gavaghan DJ, McQuay HJ: Assessing the quality of reports of randomized clinical trials: is blinding necessary? Control Clin Trial 1996, 17:1-12.

22. Higgins JPT, Green S, editors: Cochrane Handbook for Systematic Reviews of Interventions Version 5.1.0. [http://www.cochrane-handbook.org]. 
23. Shaw MD, Vermeulen M, Murray GD, Pickard JD, Bell BA, Teasdale GM: Efficacy and safety of the endothelin, receptor antagonist TAK-044 in treating subarachnoid hemorrhage: a report by the Steering Committee on behalf of the UK/Netherlands/Eire TAK-044 Subarachnoid Haemorrhage Study Group. J Neurosurg 2000, 93:992-997.

24. Vajkoczy P, Meyer B, Weidauer S, Raabe A, Thome C, Ringel F, Breu V, Schmiedek P: Clazosentan (AXV-034343), a selective endothelin A receptor antagonist, in the prevention of cerebral vasospasm following severe aneurysmal subarachnoid hemorrhage: results of a randomized, double-blind, placebo-controlled, multicenter phase lla study. J Neurosurg 2005, 103:9-17.

25. Macdonald RL, Kassell NF, Mayer S, Ruefenacht D, Schmiedek P, Weidauer S, Frey A, Roux S, Pasqualin A, CONSCIOUS-1 Investigators: Clazosentan to overcome neurological ischemia and infarction occurring after subarachnoid hemorrhage (CONSCIOUS-1): randomized, double-blind, placebo-controlled phase 2 dose-finding trial. Stroke 2008, 39:3015-3021.

26. Macdonald RL, Higashida RT, Keller E, Mayer SA, Molyneux A, Raabe A Vajkoczy P, Wanke I, Bach D, Frey A, Nowbakht P, Roux S, Kassell N: Randomized trial of clazosentan in patients with aneurysmal subarachnoid hemorrhage undergoing endovascular coiling. Stroke 2012, 43:1463-1469.

27. Wartenberg KE, Schmidt JM, Claassen J, Temes RE, Frontera JA, Ostapkovich N, Parra A, Connolly ES, Mayer SA: Impact of medical complications on outcome after subarachnoid hemorrhage. Crit Care Med 2006, 34:617-623.

28. Vergouwen MD, Etminan N, llodigwe D, Macdonald RL: Lower incidence of cerebral infarction correlates with improved functional outcome after aneurysmal subarachnoid hemorrhage. J Cereb Blood Flow Metab 2011, 31:1545-1553.

29. Etminan N, Vergouwen MD, llodigwe D, Macdonald RL: Effect of pharmaceutical treatment on vasospasm, delayed cerebral ischemia, and clinical outcome in patients with aneurysmal subarachnoid hemorrhage: a systematic review and meta-analysis. J Cereb Blood Flow Metab 2011, 31:1443-1451.

30. Vergouwen MD, Vermeulen M, van Gijn J, Rinkel GJ, Wijdicks EF Muizelaar JP, Mendelow AD, Juvela S, Yonas H, Terbrugge KG, Macdonald RL, Diringer MN, Broderick JP, Dreier JP, Roos YB: Definition of delayed cerebral ischemia after aneurysmal subarachnoid hemorrhage as an outcome event in clinical trials and observational studies: proposal of a multidisciplinary research group. Stroke 2010, 41:2391-2395.

31. Kamp MA, Heiroth HJ, Beseoglu K, Turowski B, Steiger HJ, Hänggi D: Early CT perfusion measurement after aneurysmal subarachnoid hemorrhage: a screening method to predict outcome? Acta Neurochir Suppl 2012, 114:329-332

\section{doi:10.1186/cc11686}

Cite this article as: Ma et al:: Endothelin-receptor antagonists fo aneurysmal subarachnoid hemorrhage: an updated meta-analysis of randomized controlled trials. Critical Care 2012 16:R198.

\section{Submit your next manuscript to BioMed Central and take full advantage of:}

- Convenient online submission

- Thorough peer review

- No space constraints or color figure charges

- Immediate publication on acceptance

- Inclusion in PubMed, CAS, Scopus and Google Scholar

- Research which is freely available for redistribution

Submit your manuscript at www.biomedcentral.com/submit
Biomed Central 